\title{
ÇOK ULUSLU ŞİRKETLERDE KURUMSAL KURAMIN ÖNGÖRDÜĞÜ MEŞRUIYYET KAZANMA VE EŞBİÇIMLİLIK ÇABALARINA KOŞUL BAĞIMLILIK KURAMI AÇISINDAN BİR BAKIŞ
}

\section{AN OVERVIEW FROM THE CONTINGENCY THEORY PERSPECTIVE ON LEGITIMIZATION AND ISOMORPHISM EFFORTS ENVISAGED BY INSTITUTIONAL THEORY IN MULTINATIONAL CORPORATIONS}

Cem ŞEN ${ }^{1}$

$\ddot{O} z$

Bu çalışmada, her ne kadar meşruiyet kazanma ve eşbiçimlilik kavramları kurumsal kurama ait kavramlar olsa da, söz konusu kavramların yerel şirketler için taşıdığı anlamın çok uluslu şirketlerde farklı etkilere sahip olabildiği ve koşul bağımlılık faktörlerine göre değisşebildiği sorunsalından yola çıkılmıştır. Bu bağlamda, yeni kurumsal kuram kapsamındaki meşruiyet kazanma ve eşbiçimlilik kavramlarının çok uluslu şirketler tarafindan nasıl ele alındı̆̆ ve uygulamalarının diğer yerel örgütlerden farklı olup olmadı̆̆ koşul bağımlıllk faktörleri bağlamında tartısılmaktadır. Özellikle gerekli kaynaklara ulaşma konusunda gerektiğinde kendi ana ülkeleri ve onların kurumlarını, gerektiğinde de faaliyet gösterdiği ev sahibi ülkeler ve onların kurumlarını referans alabilen çok uluslu şirketlerin kendi ana ülkelerinden (iç) ve ev sahibi ülkelerden kaynaklanan (dış) bir kurumsal ikilik (institutional duality) yaşadıkları ifade edilebilir. Çalıșma ile çok uluslu şirketler için meşruiyet kazanma ve eşbiçimliliğin hayatta kalma şansını artırmanın tek ve gerek şartı olmadı̆̆g açıklanmaya çalışılmıştır. Çok uluslu şirketlerin bu özel durumu, yeni kurumsal kuramın öne sürdüğ̈̈ kavramlara koşul bağımlılık kuramı çerçevesinde yaklaşılarak örgüt kuramları yazınının zenginleştirilmesi hedeflenmiştir.

Anahtar Kelimeler: Çok Uluslu Şirketler, Meşruiyet Kazanma, Eşbiçimlilik, Kurumsal Kuram, Koşul Bağımlılık Kuramı.

\section{Abstract}

Although legitimization and isomorphism are concepts which belong to institutional theory, their meanings can be changed when compared to local companies versus multi-national companies, and also different from the contingency theory perspective as well. When it comes to access the resources, multinational companies can reference the rules and regulations of either their home countries or host countries,

\footnotetext{
${ }^{1}$ Dr., cem.sen@ hotmail.com
} 
which causes duality. With this study, it has been tried to explain that for multi-national companies it is not the unique and required the condition to have legitimacy and isomorphism to survive. This particular situation of multi-national companies has been led to examine the concepts of institutional theory from the contingency theory perspective, hence contribute to the management and organization theory literature.

Keywords: Multi-National Enterprises, Legitimization, Isomorphism, Institutional Theory, Contingency Theory.

\section{GíRiş}

Küreselleşme ile ülkeler arasındaki ekonomik, siyasi, hukuki, sosyal ve kültürel ilişkilerin gelişmesi, her alanda çarpıcı değişikliklerin meydana gelmesi, dışa açılma ve sermayenin serbest dolaşımı, sürekli olarak daha da karmaşık hâle gelen bir çevrede yaşama zorunluluğu söz konusudur (Giddens, 1996, s. 64). Aslında küreselleşmenin, kapitalist devletlerin dünyayı kendileri için bir ortak pazar hâline getirme (Türker ve Örerler, 2004, s. 17) çabalarından başka bir şey olmadığı ifade edilebilir. Yaşanmakta olan küreselleşme süreci ile birlikte günümüzde kapitalizmin ulaştı̆̆ son nokta olan çok uluslu şirketlerin (Sklair, 2002, s. 168), küresel piyasalardaki ağırlıkları ile etkilerini artırdıkları gözlenmektedir.

Ekonomik açıdan birçok ülkeden daha güçlü olan (UN Statistics Division) ${ }^{2}$ çok uluslu şirketler incelendiğinde; ülkelerden farklı olarak kendileri dışında hiçbir kurum veya kuruluşa hesap vermedikleri, ana merkezleri tarafindan sıkı bir şekilde kontrol edildikleri ve bu merkezlerde alınan karar ve politikalar çerçevesinde yerel insiyatifleri bastırarak hareket ettikleri görülmektedir (Morgan, 1994, s. 318).

Ülke sınırlarını aşan ve başka ülkelerin ekonomik, ticari, sosyal ve hukuki alanları içerisinde kalan, yeni ve değişik örgütsel konfigürasyonları ile çok uluslu şirketlerin; tek bir kurumsal çevrenin sınırları içerisinde hareket etmek zorunluluğunu ortadan kaldırdığı (Gökşen, 2010, s. 360) söylenebilir. Özellikle gerekli kaynaklara ulaşma konusunda gerektiğinde kendi ana ülkeleri ve onların kurumlarını, gerektiğinde de faaliyet gösterdiği ev sahibi ülkeler ve onların kurumlarını referans alabilir ve oradaki kurumsal çevreye uyum sağlamaya çalışabilirler. Bu bağlamda çok uluslu şirketlerin kendi ana ülkelerinden ve ev sahibi ülkelerden kaynaklanan bir kurumsal ikilik (institutional duality) yaşadıkları (Kostova ve Roth, 2002, s. 216) ifade edilebilir. Söz konusu kurumsal ikilik bağlamında ev sahibi ülkeden/yerel çevreden kaynaklanan baskılara örnek olarak zorlayıcı baskılar (yerel hukuk, istihdam politikaları, ücretlendirme politikaları), köken ülkeden/çok uluslu şirketin kendisinden kaynaklanan baskılara örnek olarak performans değerlendirmeleri, kaynakların dağıtılması, bütçe ve finansal raporlamalar verilebilir (Rosenzweig ve Singh, 1991, s. 347). Konunun daha iyi anlaşılabilmesi için Şekil 1'deki tipolojiden yararlanılabilir.

\footnotetext{
${ }^{2}$ National Accounts Main Aggregates Database, (http://unstats.un.org/unsd/snaama/dnllist.asp)
} 
Şekil 1. Çok Uluslu Şirketlerin Karşı Karşıya Kaldığı Kurumsal İkilik

\begin{tabular}{|c|c|c|}
\hline \multirow{2}{*}{$\begin{array}{c}\text { Ev Sahibi Ülkeden/ Yerel } \\
\text { Çevreden Kaynaklanan } \\
\text { Baskı }\end{array}$} & $\begin{array}{l}\text { Yasal ve Düzenleyici Baskılar } \\
\text { - Yerel hukuk } \\
\text { - İstihdam politikaları } \\
\text { - Ücretlendirme politikaları }\end{array}$ & \\
\hline & & $\begin{array}{l}\text { - Performans değerlendirmeleri } \\
\text { - Kaynakların dağıtılması } \\
\text { - Bütçe } \\
\text { - Finansal raporlama }\end{array}$ \\
\hline & $\begin{array}{r}\text { Köken Ülke } \\
\text { Kendisinc }\end{array}$ & $\begin{array}{l}\text { k Uluslu Şirketin } \\
\text { aklanan Baskı }\end{array}$ \\
\hline
\end{tabular}

Kaynak: Rosenzweig, P.M ve Singh, J.V. (1991). Organizational environments and the multinational enterprise, Academy of Management Review, 16(2), s. 347.

Kurumsal ikiliğe örnek olarak çok uluslu şirketin ana karargâhınca tespit edilen ve global çaptaki tüm şirketlerine yaymayı düşündüğ̈̈ bir uygulamanın, yerel çevrede herhangi bir getirisi olmamasına rağmen uygulanmaya başlanması verilebilir (Kostova ve Roth, 2002, s. 216).

Her ne kadar meşruiyet kazanma ve eşbiçimlilik kurumsal kurama ait kavramlar olsa da, bu kavramların yerel şirketler için taşıdığı anlamın çok uluslu şirketlerde farklı etkilere sahip olduğu ve koşul bağımlılık faktörlerine göre değişebildiği sorunsalından yola çıkılan bu çalışmada, özellikle yeni kurumsal kuram kapsamındaki meşruiyet kazanma ve eşbiçimliliğin çok uluslu şirketler tarafından nasıl ele alındığ ve uygulamalarının diğer yerel örgütlerden farklı olup olmadığı koşul bağımlılık faktörleri bağlamında tartışılmaktadır. Ancak, yazında çok uluslu şirketlerde meşruiyet ve eşbiçimlilik kavramları üzerinde önemle durulan konular olmakla birlikte, söz konusu kavramların koşul bağımlılık faktörleri kapsamında irdelendiği araştırmalara rastlanılmamaktadır. Yeni kurumsal kuram kapsamındaki meşruiyet kazanma ve eşbiçimliliğin çok uluslu şirketlerde koşul bağımlılık faktörleri bağlamında tartışılmasına yönelik yapılan bu çalışmanın, yazındaki eksikliğin giderilmesine mütevazı bir katkı sağlayabileceği düşünülmektedir.

Bu bağlamda çalışmada öncelikle çok uluslu şirketler, kurumsal kuram ve yönetim- örgüt düşüncesine getirdikleri, koşul bağımlılık kuramı ve yönetim- örgüt düşüncesindeki yeri ile koşul bağımlılık faktörleri incelenmekte, çok uluslu şirketlerde uygulanan kurumsal düşünceler irdelenerek meşruiyet ve eşbiçimlilik uygulamalarına koşul bağımlılık faktörleri açısından yaklaşılarak önermeler oluşturulmaktadır.

\section{KAVRAMSAL ÇERÇEVE}

\section{1. Çok Uluslu Şirketler: Kapitalizmin Doruk Noktası}

Çok uluslu şirket; uluslararası sınırların ötesinde, kendi ana ülkesinin dışında en az bir yabancı ülkede üretim yapan ekonomik birim olarak tanımlanabilir (Sally,1995, s. 1). Bir başka tanıma göre ise çok uluslu şirketler, genel merkezi belirli bir ülkede olan, aktivitelerini birden çok ülkede sürdüren, işletme politikası ve stratejik kararlarını genel merkezinin planladığı şirketlerdir (Post, Lawrence, Weber ve Weber, 
1996, s. 182; Türker ve Örerler, 2004, s. 67). Diğer bir tanıma göre ise çok uluslu şirketler, iki ya da daha fazla ülkede ekonomik faaliyette bulunan, tek bir merkezden yönetilen, hukuki olarak birbirinden bağımsız, ancak ekonomik olarak birbirine bağlı ortaklıklardan, yavru şirketlerden oluşmaktadır (Aydın, 1997, s. 5).

Yapılan çok çeşitli tanımlar ışığı altında çok uluslu şirketlerin dünya çapında dış yatırımları olduğunu vurgulamak yanlış olmayacaktır. Uluslararası sermayenin sembolleri olduğu söylenebilecek çok uluslu şirketler başta petrol, enerji, otomobil, elektronik, haberleşme, bilgisayar, yazılım, finans, sigorta, ilaç, gıda, yemek, tekstil, demir-çelik ve perakendecilik (Morgan, 1994, s. 316) gibi çok değişik sektörlerde faaliyet göstermektedir. Bu şirketlerin, uluslararasılaşması ile performanslarını artırdıkları (Banalieva ve Sarathy, 2011, s. 595) ve dünya piyasasının büyük bir bölümünü kontrol ettikleri ifade edilebilir. Uluslararasılaşmanın ise Mathews’un (2006) LLL (Linking-Leverage-Learning) modelinde belirtildiği üzere öğrenmeye odaklanılması ve Dunning'in (2000) Eklektik modelindeki varlıkların keşfedilmesi ve kullanılması stratejisi motivasyonu ile başladı̆̆

Çok uluslu şirketin birçok ülkede faaliyet göstermesi ve çalışma alanının genişliği, onun çok değişik politik, ekonomik, hukuki, sosyal, kültürel ortamlarla ve çevresel kurumsal faktörlerle karşı karşıya kalmasina (Roth ve Kostova, 2003, s. 889) ve Mathews'ın (2206) LLL ve Dunning'in (2000) Eklektik modelinde belirttiği üzere durumsal olarak kaynaklara ulaşmasında çeşitli zorluklarla karşılaşmasına neden olmaktadır. Bu bağlamda, çok uluslu şirketler; hükümetler, sendikalar, bankalar, endüstriyel birlikler, alt yükleniciler, hammadde sağlayıcıları ve müşterilerden oluşan bir ağda sürekli bir ilişki ve etkileşim içerisindedir (Sally, 1995, s. 206). Söz konusu ilişki ve etkileşimler çok uluslu şirketlerin devamlı gelişme ve değişmelerine neden olmaktadır. Bu kapsamda, çok uluslu şirketlerin örgüt yapısı sürekli bir büyüme (üretimin, satışların, çalışanların, müşterilerin, satıcı sayısının, finansman kaynaklarının artması) dolayısıyla da risk ve belirsizliklerin artması ile karşı karşıya kaldığı (Türker ve Örerler, 2004, s. 69) ifade edilebilir. Özellikle hangi ülkelerde, hangi düzeyde, hangi yöntemlerle, ne kadar yatırımla, yerel ortak kullanarak mı ya da kullanmadan ve hangi rekabet şartlarında gibi önemli stratejik nitelikteki kararların verilmesi; sonrasında ise pazara hâkim olma ve rakiplerin kontrol altında tutulması karşılaşılabilecek muhtemel sorunlar olacaktır. Çok uluslu şirketlerin, bu sorunları aşmak için kaynaklarını koruma ve riskleri paylaşma (Eisenhardt ve Schoonhoven, 1996, s. 136) anlayışından hareketle, faaliyetlerini en az maliyetle yapabilecekleri yerleri seçerek, büyümelerini, elde ettikleri faydaların maliyetlerine eşit olduğu noktaya kadar devam ettirecekleri (Aydın, 1997, s. 36-37) ifade edilebilir.

Meydana gelen gelişim ve değişim süreci içerisinde sayısı ve etkinliği büyük artış gösteren, ekonomik açıdan önemli kaynaklara ulaşan çok uluslu şirketlerin küreselleşme süreci ile de çok yakından ilişkisi bulunmaktadır (Sally, 1995, s. 10). Herhangi bir sektördeki çok uluslu şirketin, sektör içerisindeki büyüklüğü, patent ve telif hakları nedeniyle sahip olduğu rekabet ve piyasa gücü (Hillman ve Wan, 2005, s. 327), hem ana hem de ev sahibi ülkede tekel gibi etkili bir sorun teşkil edebilmektedir. Çok uluslu şirket, kolayca bulunduğu sektöre giriş engelleri yaratabilmekte, fiyatı ve miktarı kontrol altına alarak haksız baskılar kurup fiyatları aşağı çekerek küçük rakiplerini piyasadan silebilmektedir (Türker ve Örerler, 2004, s. 58). Etik olmamakla birlikte çok uluslu şirketlerin doğasında kapitalizmin doruk noktası olan daha, çok daha fazla kâr etmek vardır (Oksay, 1998, s. 22). Bu bağlamda düşünüldüğünde, zaten adil olmayan yüksek kazançlara sahip çok uluslu şirketlerin ekonomik anlamda ne kadar güçlü olabileceği (McIntyre ve Ivanaj, 
2009, s. 17) gerçeği ile karşı karşıya kalınmaktadır. Özellikle az gelişmiş ya da gelişmekte olan ülkelerde yaptıkları yatırımlar ile teknoloji transferi sağlayarak o ülkelerdeki istihdamın artırılmasına dolayısıyla yerel ekonomiye verdikleri katkıya karşılık, mevcut doğal kaynakları ve ucuz işgücünü (Tayland, Tayvan, Malezya, Hindistan, Meksika vb.) sömürme potansiyeli (Post vd., 1996, s. 176) de gözden kaçırılmamalıdır.

Çalışmanın bu bölümünde, çok uluslu şirketlerde kurumsal kuramın öngördüğü meşruiyet kazanma ve eşbiçimlilik çabalarına koşul bağımlılık kuramı açısından ele alınmasına geçilmeden önce, kurumsal kuram ve yönetim- örgüt düşüncesindeki önemi incelenmektedir.

\subsection{Kurumsal Kuram ve Yönetim- Örgüt Düşüncesine Getirdikleri}

Kurumsal kuram, örgütlerin yapı ve süreçlerinin içerisinde bulundukları kurumsal çevreye uyumları sonucunda biçimlendiğini, örgütlerin yaşamlarını sürdürebilmek için benzer kurumlara eşbiçimli hâle gelerek kendilerini meşru kılmaları (meşruiyet sağlamaları) gerektiğini belirtmektedir (Meyer ve Rowan, 1977, s. 346,352; DiMaggio ve Powell, 1983, s. 149; Scott, 2003, s. 881). Meyer ve Scott'a (1983, s. 201) göre meşruluk, örgütün içerisinde bulunduğu sosyal ve kültürel çevre ile uyumunu sağlayan bir olgudur ve genel olarak örgütler, faaliyet gösterdikleri sosyal ve kültürel çevre içerisinde meşru görülmelerini sağlayacak düzenleme ve aktivitelerde bulunurlar. Başka bir ifade ile örgütlerin yaşamlarını sürdürebilmek için sadece etkin ve etkili olmaları yeterli değildir, kurumsal çevre içerisinde ne derece kabul gördükleri daha da önemlidir (Çakar ve Danışman, 2012, s. 241). Bu bağlamda belirli bir alanda faaliyet gösteren örgütler, kendileri için her zaman kilit bir rol oynayan meşruiyet kaygısı ile içerisinde bulundukları toplumsal düzene has yaklaşım ve değerler ile uyumlu yapılanma ve faaliyetler sergileme neticesinde giderek birbirlerine benzemeye başlarlar (DiMaggio ve Powell, 1991, s. 64).

Kurumsal kurama göre kurumsal çevre; teknik çevreden çok, bireyleri ve onların meydana getirdiği örgütleri oluşturan değerler, normlar, inançlar ve kabul görmüş davranışlarla örülmüş bir ağdır ve efsaneleşmiş örgütsel yapı, hizmet, teknik, politika ve programları kapsamaktadır (Meyer ve Rowan, 1977, s. 340). Söz konusu ağ, içerisinde barındırdığı aktörlerin (bireyler ve örgütler) eylemlerine şekil veren ussal bir çevre sunmaktadır (Hasselbladh ve Kallinikos, 2000, s. 698). Zamanla bir takım örgütsel yapı ve uygulamalar diğerlerine nazaran daha çok kabul görmeye başlar ve o yapı ve uygulamalar öyle bir önem kazanır ki, fayda sağlayıp sağlamadığına bakılmaksızın varlıkları ve meşruiyetleri sorgulanmaz bir hâle gelir (DiMaggio ve Powell, 1983, s. 148).

Bugün bilinen şekliyle kurumsal kuram 1970'li yıllarda gelişmeye başlamakla birlikte, gelişiminde ekonomi, siyaset bilimi ve sosyolojideki kurumsal düşüncenin katkısı olmuştur; özellikle sosyalbilimci Weber, Parsons, Merton ve Selznick'in katkıları en öne çıkan çalışmalardır (Scott, 1995, s. 1). İdeal örgüt olarak tanımladığı bürokrasi yaklaşımının fikir babası Weber, çalışmalarında kurum ve kurumsal yapı ifadelerini doğrudan kullanmasa da toplumdaki kuralların (yasal, geleneksel, kültürel vb.) sosyal yapıları belirlediği ve davranışı şekillendirdiğini ifade etmiştir (Scott, 1995, s. 11-12). Parsons kurumsallaşmayı, sosyal aktörlerce toplumsal değer ve normlara uyulması olarak tanımlamıştır (Neuman, 2012, s. 140). Parsons'a göre örgütler; teknik, yönetsel ve kurumsal olmak üzere üç ayrı sorumluluk ve kontrol bölgesini kapsamaktadır (Thompson, 1967, s. 10-11). Teknik yap1 üretimde verimliliğin sağlanmasına, yönetsel yapı örgüt ve çevresi ile arasında aracıllğın sağlanmasına, kurumsal yapı ise örgütün amaçlarına ulaşması için gerekli meşruiyetin kazanılmasına odaklıdır. Selznick'in çalışmalarına ilham 
kaynağı olan Merton, toplumsal kurumların faydalı olabileceği gibi zararlı da olabileceklerini savunmuştur (Scott, 1995, s. 17). Çünkü mevcut kurallara körü körüne uymak, onları birer araç olarak kullanmak yerine amaç hâline getirmek, bürokratik kurumun düzgün işlemeyen bir yapı sergileyebileceği gerçeğini gündeme getirmektedir.

Tarihsel gelişimi içerisinde kurumsal kuramı eski ve yeni olarak iki bölüm halinde incelemek mümkündür. Selznick'in (1996) eski kurumsal kuram yaklaşımı, Tennessee Valley Authority (TVA) araştırmasına dayanmaktadır. Bu çalışma ile Selznick, kurumsal kurama ilişkin öngörülerini sahada test etme imkânı bulmuştur. Söz konusu çalışmada yer alan TVA, 1930’lu yıllarda Tennessee bölgesinde, çevreyi koruma, enerji üretimi, ormancılık, suyolları, gübre üretimi ve çiftliklerde çalışan fakir zenci kesime ulaşmak gibi birçok boyutu olan kapsamlı bir bölgesel kalkınma projesini yürütmek üzere kurulmuş bir örgüttür. Selznick, TVA’nın fakir bölge halkını kalkınma sürecine katma çabalarının, güçlü çıkar gruplarının temsilcilerinin örgütün çeşitli karar organlarına yerleşerek örgütün kontrolünü ele geçirmelerine ve başlangıçta benimsenen amaçlarından sapmasına yol açtığını, örgütlerin göründükleri kadar ussal olmadıklarını, ancak bazı değerleri somutlaştırma vasıtaları olduklarını tespit etmiştir (Selznick, 1996, s. 270). Burada özellikle dikkat çeken husus, örgütün zaman içerisinde kendi özgün yapısı ve amaçlarının çevrenin belirleyici baskısıyla dönüşüme uğradığının (Sargut, 2012, s. 245) gözlemlenmesidir. Örgütlere bu açıdan yaklaşıldığında, onların öncelikle hayatta kalma amaçlarını gerçekleştirmeye çalışan ve insanlardan bağımsız kendine özgü varlıklar olduğu söylenebilir.

Selznick (1996, s. 271) örgüt ve kurum arasındaki farkın gözden kaçırılmaması gerektiğini; bazı örgütlerin sadece birer ussal araç olarak örgüt olduğunu; bazı örgütlerin ise, kendilerini diğerlerinden farklılaştıran bir oturmuşluğa ulaşarak kurum hâline geldiğini belirterek; kurumsallaşmayı, çevredeki grupların değerlerine uyumlanılan bir süreç olarak tanımlamaktadır. Burada söz konusu edilen çevre, örgütlerin içerisinde yaşadığ 1 çevre olup, teknik ve kurumsal çevre olarak iki boyutta ele alınmaktadır. Teknik çevre, örgütlerin üst düzey performans göstererek mal ve hizmet üretimini etkinlik ile etkililik odaklı sürdürdüklerinde ödüllendirildikleri çevredir; kurumsal çevre ise örgütlerin kurallara, sosyal ve kültürel çevresel koşullara uyuma odaklı oldukları sürece ödüllendirildikleri çevredir (Scott ve Meyer, 1991, s. 121,125).

Meyer ve Rowan'a (1977, s. 348-349) göre, örgütler genellikle, meşruiyet kazanmak, gerekli kaynaklara ulaşmak ve hayatta kalma şansını artırmak için, bulundukları sektörde ussallaştırılmış kurumsal kurallara uymak zorunda kalmakta; örgütler, bu kuralların rehberliğinde verimliliklerini artırmak için değil, meşruiyet kazanmak ve kendileri için belirsizliği azaltmak için çabalamaktadır. Örgütler ve örgüt içerisindeki bireyler toplumsal değer, norm, kural, inanç ve davranışlardan örülmüş karmaşık bir ağ ile çevrilmiştir; söz konusu ağ, aktörlerin faaliyetlerini şekillendiren ussal bir çevre ile içiçedir (Hasselbladh ve Kallinikos, 2000, s. 698-699). Örgütler bu şartlar altında kendilerini etkileyen çevrelerindeki kurumları benimseyerek, onlarla eşbiçimli hâle gelmektedirler. Meyer ve Rowan (1977, s. 355) iki tür çevresel eşbiçimliliğin var olduğunu kabul etmektedir; birincisi, koşul bağımlılık ve popülasyon ekolojisi kuramının vurguladığı, çevreyle teknik ve mübadele bağımlılığından doğan ve rekabet merkezli eşbiçimlilik, diğeri ise yukarıda sözü edilen kurumsal çevreyle olan meşruiyet kazanma merkezli eşbiçimliliktir. 
Bu kapsamda düşünüldüğünde, örgütlerin kurumsal yapılarını oluştururken verimliliği artırmak ve meşruiyetlerini korumak arasında bir ikilemle karşı karşıya geldikleri ve bu nedenle de sürekli olarak birtakım seçimler yapmak zorunda kalabilecekleri söylenebilir. Örgütler, bu gibi durumlarda ikilemi ortadan kaldırmak için törensel gerekliliklere direnç gösterme, kurumsallaşmış yapılarını koruyarak dış çevre ile ilişkilerini kesme, benimsedikleri kurumsallaşmış yapı ile iş gerekleri arasında çelişki olduğunu gündeme getirme ve teknik gereklere göre davranıp gelecekte reform yapacakları konusunda sözler verme şeklinde kısmi çözüm yolları uygulayabilirler (Meyer ve Rowan, 1977, s. 356). Örgütler söz konusu çelişkiyi kısmi çözüm yolları ile değil de kalıcı olarak çözmek isterlerse birbirleriyle ilişkili iki araca başvurabilirler, bunlar; ayırma ve güven yaratmadır (Meyer ve Rowan, 1977, s. 357). Özen (2010, s. 257258) ayırmayı, kurumsallaşmış örgütlerin biçimsel yapılarını günlük faaliyetlerden arındırmaları; güven yaratmayı ise, kurumsallaşmış örgütlerin verimli ve güvenilir olduklarını göstermeleri olarak tanımlamaktadır. Bu bağlamda kurumsal çevrenin, örgüt-çevre ilişkisine meşruiyet çerçevesinde yaklaştığı ifade edilebilir. Sonuç olarak örgütlerin, kurumsal çevreleri tarafından kurgulandıkları, onlara benzemeye çalıştıkları ve biçimsel örgütlerin karşılıklı bağımlılıklar yoluyla kurumsal çevrelerine uyumlu hâle geldikleri (Meyer ve Rowan, 1977, s. 346) öne sürülmektedir.

Yönetim ve örgüt yazınında yeni kurumsalcılık olarak adlandırılan akımda ise kurumları incelemeye yönelik disiplinlerarası araştırmaların artışı ile birlikte gelinen noktada, sosyal yapı ve davranışların açıklanmasında; kuralların rolü, kültürün etkisi ve tarihin önemine de artan bir ilgi söz konusudur (Scott, 2003, s. 879-880). Yeni kurumsalcılara göre, sosyal bağlam içerisinde diğerleri ne yapıyorsa onu yapmaya çalışmak ya da yapıyor olmak sosyal davranışın genel bir biçimi olarak karşımıza çıkmakta, örgütsel alanda bunu gerektiren en büyük unsur ise örgütlerin içerisinde bulunduğu belirsizlik ve sınırlamalar olmaktadır (DiMaggio ve Powell, 1983, s. 147). Örgütler, söz konusu belirsizliği azaltmak ve dikte edilen sınırlamalar içerisinde hareket edebilmek için ya kurumsal hale gelmiş kural ve uygulamaları kabul edip takip etmek (Zucker, 1977) ya da kendi yapılarında birtakım değişiklikler uygulamak zorunda kalabilmektedir.

Yeni kurumsalcılar, yazına meşruiyet kazanma merkezli kurumsal eşbiçimlilik (Deephouse, 1996, s. 1024; Suddaby ve Greenwood, 2005, s. 37) kavramını kazandırmışlar ve bu kavramdan yola çıkarak, örgütlerin, gerek öykünmeci (belirsizliğe karşı standart tepkilerden kaynaklanan), gerek zorlayıcılık (yasal, politik etkiden ve meşruiyet sorunundan kaynaklanan), gerekse normatif (meslekleşme/profesyonelleşmeden kaynaklanan) baskıların etkisiyle birbirlerine giderek daha çok benzemeye başladıklarını ortaya koymuşlardır (DiMaggio ve Powell, 1983, s. 150-154). Bu yapı ve uygulamalar ussal gerekçelerle oluşturularak kurumsallaşmakta ve kendilerini benimseyen örgütlere teknik yararının ötesinde meşruiyet sağlamakta, hayatta kalan örgütler arasındaki bu uygulamalar hızla yayılarak örgütsel alanda kurumsal eşbiçimlik oluşturulmaktadır (DiMaggio ve Powell, 1991, s. 65-66).

Benzer şekilde, Deephouse da yaptığı çalışmalar sonucunda eşbiçimliliğin meşruiyeti artırdığını ortaya koymuştur (Deephouse, 1996, s. 1034-1035). Bu nedenle, örgütlerin ürkütücü bir biçimde birbirlerine benzemeleri araştırılması gereken bir husus olarak ortaya çıkmaktadır (Özen, 2010, s. 265). Bu bağlamda kurumsalcıların, eşbiçimlilik olgusunun ardındaki kurumsal süreçleri (Sargut, 2009, s. 60) irdelemeleri, değişik bir bakış açısı ile örgütleri içerisinde bulundukları kurumsal çevre ile ilişkilendirerek 
ele almaları, örgütsel analizlere farklı bir boyut kazandırmıştır (Bolat ve Seymen, 2006, s. 225). Son toplamda kurumsal çevreye uyumun; meşruiyeti ve böylece de dışsal desteği sağladıği ifade edilebilir (Donaldson, 2008a, s. 18).

Görüldüğü üzere kurumsal kuramın vurguladığı kurumsal çevreler; başta yasal, sosyal ve kültürel faktörlerden oluşan ve genellikle de ulusal sınırlar ile uyumlu çevrelerdir (Rosenzweig ve Sing, 1991, s. 342). Ancak, bu makalenin konusunu teşkil eden çok uluslu şirketler, birden çok ülkede faaliyette bulundukları için herhangi bir ulusal sınır içerisinde düşünülemezler. Özellikle çok uluslu şirketin kurumsallaşması kapsamında takip ettiği strateji ve uygulamalarını, ulusal sınırların dışına taşmış ve küresel çapta dört bir yana dağılmış tüm şirketlerine yansıtarak onları kendi ile eşbiçimli hâle getirmesi (Kostova ve Zaheer, 1999, s. 72), sürdürülebilir rekabet avantajı ve başarısının en önemli kaynağını oluşturduğu vurgulanabilir.

Makalenin bu bölümünde, koşul bağımlılık kuramı ve yönetim-örgüt düşüncesindeki yeri, çok uluslu şirketlerin koşul bağımlılık faktörleri kapsamındaki yaklaşımları incelenmektedir.

\subsection{Koşul Bağımlılık Kuramı ve Yönetim-Örgüt Düşüncesindeki Yeri}

1960’lı yıllarda yönetim ve örgüt alanında köklerini Genel Sistem Teorisi’nden (Bertalanffy, 1950, s. 139) alan, yönetimsel açıdan ve örgütleri inceleme biçimi ile kendinden önceki yönetim kuramlarından ayrılan yeni bir yaklaşım (Cohen, 2006, s. 112) akademik gündeme gelmiştir. Yönetim yazınındaki araştırmaları bugün de domine etmeye devam ettiği (Donaldson, 2001, s. 37) iddia edilen ${ }^{3}$ ve Koşul Bağımlılık Kuramı olarak adlandırılan bu kuram, örgütlerin yaşamlarını sürdürebilmeleri ve iyi performans göstermeleri için mevcut koşullara uyum göstermelerini şart koşmaktadır (Thompson, 1967, s. 78; Lawrence ve Lorsch, 1967, s. 4; Donaldson, 1996, s. 63; 2001, s. 6; 2008a, s. 3).

Klasik yönetim yaklaşımlarının özünde; en iyi ve evrensel bir örgüt yapısının tanımlanması ile yönetimin temel ilkelerinin ortaya konulması yatmaktadır (Tüzün, 2012, s. 21). Oysa bilgi ve teknolojinin ateşlediği değişme ortamı, örgütsel yapılar ve işleyiş üzerindeki baskısını arttırmış ve yaşamlarını sürdürmek isteyen örgütlerin, çevresel değişimlere duyarlı olmalarını şart koşan yeni arayışları (Sargut, 2012, s. 239) gündeme getirmiştir. Bu arayışlardan birisi olan koşul bağımlılık kuramı, en iyi ve evrensel örgüt yapısı ile yönetimin temel ilkelerinin koşullar tarafından belirlendiğini ifade etmektedir (Donaldson, 1996, s. 61; 2001, s. 7; 2008a, s. 4). Bu bağlamda, yöneticiler için her koşulda geçerli tek bir örgüt yapısı bulunmamakta, yöneticilerin örgüt yapılarını içerisinde bulunduğu çevre, teknoloji, büyüklük, strateji ve kültür gibi koşul bağımlılık faktörlerine uyarlamaları gerekmektedir (Morgan, 1994, s. 42; Donaldson, 1996, s. 61; 2001; Cohen, 2006, s. 122). Koşul bağımlılık faktörlerinden özellikle çevre ve teknoloji örgütler için temel belirsizlik kaynağı olup, bunlardaki değişiklikler örgütlerde çok farklı yapılanmalara sebep olmaktadır (Thompson, 1967, s. 13). Kuramda koşul bağımlılık faktörlerine (bağlamsal/bağımsız değişkenlere) ilave olarak yapısal (bağımlı) değişkenler de ele alınmıştır. Söz konusu yapısal değişkenler; biçimselleşme, uzmanlaşma, merkezileşme, yetki hiyerarşisi ve standartlaşma olarak sıralanabilir (Sargut, 2010, s. 36).

\footnotetext{
${ }^{3}$ Ki bu konuda Scott (1995, s. 31), aynı etkinin Kurumsal Kuram tarafından gerçekleştirildiğini öne sürmektedir.
} 
Koşul bağımlılık kuramının oluşturulmasındaki kilometretaşı çalışmalar incelendiğinde; örgüt ve çevre ilişkisinde Burns ve Stalker (1961), Emery ve Trist (1965), Thompson (1967), Lawrence ve Lorsch (1967) ve Duncan'ın (1972); örgüt ve teknoloji ilişkisinde Woodward (1965), Perrow (1967), Thompson (1967) ve Aston Grubu'nun (1969); örgüt ve büyüklük ilişkisinde Blau’nun (1970); örgüt ve strateji ilişkisinde ise Chandler'in (1962) büyük katkıları olduğu görülmektedir.

Örgüt ve çevre ilişkisinde; Burns ve Stalker (1961) biçimselleşme, merkezileşme, uzmanlaşma ve iş bölümünün yüksek olduğu mekanik örgüt yapısı ile birlikte çalışma, karşılıklı fikir alışverişi ve kararlara katılımın öne çıktığı organik örgüt yapısını; Thompson (1967) çevresel belirsizliği azaltmada içsel (tampon oluşturma, öngörme, kemer sıkma ve sınır genişletme) ve dışsal (rekabetçi ve işbirliği stratejileri) uygulamaları; Lawrence ve Lorsch (1967) örgütlerin ve alt sistemlerinin çevrenin taleplerine farklılaşma ve entegrasyon kapsamında verdikleri tepkileri ortaya koymuşlardır. Bu bağlamda yapılarını değişen çevre koşulları ile uyumlandırabilen örgütler başarılı olmaktadır.

Örgüt ve teknoloji ilişkisinde Woodward (1965) birim, kitlesel ve süreç üretimi teknolojilerini; Perrow (1967) rutin, rutin olmayan, mesleki ve mühendislik teknolojilerini; Thompson (1967) bağl1, çözümleyici ve yoğun teknolojileri ortaya koymuşlardır. Bu kapsamda yapılarını kullandıkları teknolojileri ile uyumlandırabilen örgütler başarılı olmaktadır.

Donaldson (2001), koşul bağımlılık kuramının temel paradigmasını; koşul bağımlılık faktörleri ile örgüt yapısı arasındaki ilişki, bu faktörlerin yapıyı belirlemesi ve örgütün yapısal değişkenleri ile koşul bağımlılık faktörleri arasındaki uyum olarak özetlemektedir (Donaldson, 2001, s. 7). Örgütlerin etkinlik ve etkililiği için yöneticilerin belirsizlikler karşısında ve özellikle de değişen çevreye uyumlu yapıyı tasarımlayarak örgütün çevreyle sürekli uyum içerisinde olmasını sağlamalıdır (Cohen, 2006, s. 117). Söz konusu uyum, örgütlerin yapısal farklılaşmalara gitmeleri ile mümkün olabilmektedir. Uyum sağlandığında örgüt yüksek performansa erişmekte, uyumsuzluk başladığında ise örgütün performansı düşmeye başlamaktadır (Sargut, 2010, s. 37-38).

Son toplamda koşul bağımlılık faktörlerine uyumun; örgüt için üst derece içsel etkililiği sağladığı ifade edilebilir (Donaldson, 2008a, s. 18). Ancak, çok uluslu şirketler dünya çapında yayılmış olması nedeniyle çok çeşitli çevrelerle ve bunların etkileriyle karşı karşıya kalmaktadır. Bu nedenle çok uluslu şirketlerin yatırım yaptıkları ülkelere etkileri ile bu ülkelerdeki kurumların çok uluslu şirketlerin uygulamalarına etkilerinin neler olabileceği merak uyandıran konular olarak karşımıza çıkmaktadır. Çalışmada ele alınan koşul bağımlılık faktörlerinden çevresel uyum (özelliklede ana köken ülkeden kaynaklanan içsel uyum) ve teknolojik üstünlükleri çok uluslu şirketlerin başarısında başat oyuncu olarak kendini göstermektedir.

Çalışmanın bu bölümünde, çok uluslu şirketlerde kurumsal kuramın öngördüğü meşruiyet kazanma ve eşbiçimlilik çabaları irdelenmektedir.

\subsection{Yeni Kurumsal Kuram Açısından Çok Uluslu Şirketlerde Meşruiyet Kazanma ve} Eşbiçimlilik Çabaları

Çok uluslu şirketlerin ayırt edici özellikleri ile teorik göstergelerine kurumsal kuram kapsamında yaklaşıldığında, bazı önemli konuların çok uluslu şirket yapılanmasını tatmin edici düzeyde açıklayamadığı düşünülebilir. Özellikle yeni kurumsal kuram kapsamındaki meşruiyet kazanma maksatlı eşbiçimliliğin, 
çok uluslu şirketler tarafından nasıl ele alındığı ve uygulamalarının diğer yerel örgütlerden farklı olup olmadığı tartışılabilir.

Mevcut uluslararası yönetim yazını kurumsal kuram uygulamaları açısından tarandı̆̆ında üzerinde sıklıkla araştırma yapılan konuları şu şekilde sıralanabilir;

- Ulusal çevrenin düzenleyici, bilişsel ve normatif süreçler yoluyla ulusal kurumsal profil oluşturma çabası,

- Ulusal sistemlerde kurumsal geçiş yoluyla büyük çaplı değişim sürecinin kavramsallaştırılması,

- Kurumsal yerleşiklik açısından ulusal işletme sistemlerinin karşılaştırılması,

- Örgütlerde eşbiçimlilik baskıları ile sonuçlanan uygulamaların benzerliklerinin açıklanması,

- Örgütün kurumsallaştırılması için çok uluslu şirketin birimleri ve çevresel sınırında yapılan çalışmaların kısıtları üzerinde çalışılması,

- Çok uluslu şirketler ve faaliyet gösterdikleri ülkedeki çevre ile olan ilişkilerinin meşruiyet ve yabancı olmanın getirdiği yükümlülüklerin açıklanmasıdır (Kostova vd., 2008, s. 994-996).

Çok uluslu şirketler bir taraftan uluslararası kontrol maksadıyla merkez tarafından yayılan zorlayıcı eşbiçimli baskılar, diğer taraftan da faaliyette bulunulan ülkelerin kurumsal sistemlerine uyumlanmaları yönünde yerel çevredeki güçlerin baskıları ile karşı karşıya kalmaktadırlar (İlhan, 2005, s. 82). Çok uluslu şirketin kendi ana merkezinden kaynaklanan iç baskılar ile ev sahibi ülkedeki kurumsal çevreden kaynaklanan dış baskılar, kurumsal ikiliğin yaşanmasında ana neden olarak ortaya çıkmaktadır (Hillman ve Wan, 2005, s. 325). İç baskıların temelinde ana merkezin kurumsallaşmış strateji ve uygulamaları ile uyumlu ve eşbiçimli olmak (Kostova ve Zaheer, 1999, s. 72), dış baskıların temelinde ise ev sahibi ülkedeki kurumsal çevreye yabancı olmak (Zaheer, 1995, s. 341) yatmaktadır. Bu açıdan yaklaşıldığında çok uluslu işletmelerin hayatta kalabilmek için karşı karşıya kaldığı baskıları başarılı bir şekilde yönetebilmeleri gerektiği değerlendirilebilir. Çevrenin örgütsel yapıyı ve kararları etkilemekteki gücü göz ardı edilmemelidir. Çok uluslu şirketlerin yapısal farklılıkları, özellikle karmaşık yapısı, kültürü, birimler arası güç çekişmeleri, çıkar çatışmaları ve ev sahibi ülkenin çevresel baskıları nedeniyle yeni kurumsal kuramın farklı şekilde yorumlanmasını gündeme getirdiği düşünülebilir.

Örgüte özgü bir kimlik inşa etmek, onu geliştirmek ve korumak için çok uluslu şirketlerin dünya genelinde faaliyette bulunan bağlı kuruluşlarındaki veya ortak girişimlerindeki bireyleri yönetmede gerekli tutarlılığı sağlaması gerekmektedir; ancak, şirketin etkili bir şekilde yerel koşullara uyum sağlaması, farklı toplumların belirli kültürel ve kurumsal ihtiyaçlarına uyum sağlamasını zorunlu kılmaktadır (İlhan, 2005, s. 85). Çok uluslu şirketin küresel ölçekteki konumu merkezle tutarlı olmayı gerektirebilirken, yerel kurumsal çevre çeşitliliği ve farklılaşmayı gerektirebilmektedir; özellikle yerel çevrelerde, örgüt bünyesinde içsel tutarlılık baskılarını etkisiz hâle getirip, yerel uygulamaları benimsemesi yönünde çok uluslu şirketlere baskılar yapılmaktadır (DiMaggio ve Powell, 1983, s. 150).

Çok uluslu şirketin yabancı ülkelerde yatırım yapması, kendi ana (köken) ülkesindeki kurumsal çevreye (çevrenin sağladığı kaynaklara) bağımlılığı azaltıcı bir sonuç doğurabilir; ev sahibi ülkedeki kaynaklara erişim ise çok uluslu şirketin uyum sağlayıcı değişiklikler yapmasını gerektirebilir (Whitley, 
2000, s. 858). Ancak yeni kurumsal kuramın genellikle meşruiyet kazanmak, kaynaklara ulaşmak ve hayatta kalma şansını artırmak için bulunulan ortamdaki kurumsal kurallara uymak zorunda olmaları ve bu kapsamda çevredeki kurumları benimseyerek onlarla eşbiçimli hâle gelmeleri gerektiği kuralı, bazı çok uluslu şirketlere özellikle de ana ülkesi Uzak Doğu kökenli (Japonya, Güney Kore ve Tayvan gibi) olan şirketlerin uygulamaları ile uyuşmamaktadır (Whitley, 1999, s. 16). Benzer şekilde örgütsel yapısını belirlemiş ve standarda oturtmuş (kurumsallaşmış) çok uluslu şirketlerin söz konusu yapıyı dünya çapında uygulamaya devam ettikleri ve herhangi bir değişikliği kabul etmedikleri görülmektedir. Örneğin ABD menşeli Procter \& Gamble, McDonalds ve Burger King'in örgüt yapısı, dünyanın her yerinde aynı şekildedir (Rosenzweig ve Singh, 1991, s. 346). Küresel telefon şirketlerinden AT\&T'nin kurumsal uygulamalarını gittiği her ülkede istisnasız aynı şekilde uygulaması da bu konuda verilebilecek örneklerden birisidir. AT\&T, çalışanlarına uyguladığı ücretlendirme ve haftalık çalışma saatlerini Meksika'daki yerel çevreyle uyuşmasa da, bu konudaki uygulamalarını kabul ettirmiştir. Bu durum, tüm çok uluslu şirketlerin örgütsel formunu değiştirmesi veya ev sahibi ülkenin kurumsal çevresinden etkilenmesinin her zaman gerçekleşmeyebileceğini göstermektedir.

Önerme1: Kurumsal kuramın meşruiyet kazanma ve eşbiçimlilik kavramlarl, çok uluslu şirketlerde tam uygulama alanı bulamamaktadır.

Çok uluslu şirketlerin ev sahibi ülkede karşılaştıkları çevre ve çok değişik yapıdaki örgütler, değişik formlarda oluşmuşlardır; ancak, çok uluslu şirketlerin uluslararası boyutta yatay ve dikey bütünleşmelerle ortaya koydukları esnek ve dinamik örgüt yapıları, sektörde söz sahibi olmaları ve küresel çapta meydana gelebilecek istikrarsızlıklardan etkilenme olasılıklarının görece düşük olması, yerel kurumsal etkilerden daha az etkilenmelerini sağlamaktadır (Kostova vd., 2008, s. 999). Özellikle ekonomik açıdan sınırlı güce sahip gelişmekte olan veya bu gücü hemen hemen hiç olmayan az gelişmiş ülkelerin yerel kurumsal çevreleri yeterince güçlü değildir. Söz konusu kurumsal çevreler, çok uluslu şirketleri eşbiçimliliğe zorlayacak sınırlı kapasiteye sahiptir, ev sahibi ülkenin çoğunlukla çok uluslu şirketler hakkındaki bilgisi eksiktir ve bu nedenle de çok uluslu şirketlerin izlemesi için oluşturulmuş kesin kurumsal formlar mevcut değildir (Koene ve Ansari, 2011, s. 512).

Yerel çevrenin, çok uluslu şirketlerin muhtaç olduğu tüm kaynakları kontrolü altında tutamadığı; çok uluslu şirketlerin yasal sınırlar içerisinde hareket ettiği sürece, kaynaklara ulaşmada ve yerel kurumsal çevreyle olan ilişkilerini yönlendirmekte serbest olduğu söylenebilir (Kostova vd., 2008, s. 999). Çok uluslu şirketler için önemli olan küresel çapta bulundukları sektördeki uygulamalar ve gelişmeler, kendi ana ülkelerince belirlenen kurallardır. Bunun yanında ev sahibi ülkedeki kurumsal çevreyi de kendi amaçları doğrultusunda kullanma eğilimleri çok uluslu şirketlerin kendilerine özgü ve tahmin edilemeyen uygulamalarını (Koene ve Ansari, 2011, s. 513-514) gündeme getirmektedir.

Çok uluslu şirketlerin kendi ana ülkelerine olan bağımlılıklarının azalmadığı, ev sahibi ülkelerde, ana ülkelerinde geliştirmiş oldukları kontrol mekanizmalarını kullandıkları, yapılan çalışmalar ile tespit edilmiştir (Harzing ve Sorge, 2003, s. 206). Bu noktadan hareketle çok uluslu şirketlerdeki eşbiçimlilik kavramına farklı yaklaşılması gerektiğine dikkat çekilerek, tüm çok uluslu şirketlerin, kendi ülkesinin etkilerini diğer ülkelere taşıdığı söylenebilir. 
Kullanılan ve sürekli geliştirilen ortak teknolojiler, aynı sektör içinde gerçekleşen stratejik planlamalar, başarılı uygulamaların yayılması ile çok uluslu şirketler ve faaliyet gösterilen ülkedeki rakipler arasında gerçekleşen örgütsel öğrenme sonucu, çok uluslu şirketler bulunulan ülkedeki örgütlere benzemek yerine, oradaki örgütlerin birbirine benzemesine büyük katkı yaparlar (Mueller, 1994, s. 422). Örneğin Marriott, Hong Kong’ta açtı̆̆ lüks otelde çalıştırdığı personeli haftada beş gün çalışmak üzere işe alarak, yerel altı gün çalışma normuna meydan okumuştur (Basler, 1989). Başlangıçta Hong Kong'lu yetkililer Marriott'u uyarmış, resmi turizm rehberlerindeki listelerden çıkarmış ve yararlandığı çeşitli kolaylıkları iptal etmiştir. Ancak 18 ay gibi bir süre zarfında, diğer birkaç çok uluslu şirketin de aynı uygulamayı takip etmesi neticesinde, Hong Kong'lu yetkililer haftada beş gün çalışılmasını kabul etmişlerdir. Marriott, bu şekilde dünyanın her yerinde uygulamakta olduğu prensibini, yerel çevreyi değiştirerek kabul ettirmiştir. Bunda çok uluslu şirketlerin dünya çapında tutarlı bir şekilde takip ettiği politikaların büyük pay sahibi olduğuna dikkat çekilebilir; ancak, çok uluslu şirketin etkisi, ev sahibi ülkenin kurumları karşısındaki kredibilitesi (Hillman ve Hitt, 1999) ve gücü ile doğru orantılıdır (Whitley, 2000, s. 880-881).

Önerme2: Çok uluslu şirketler, ev sahibi ülkelerdeki norm ve değerlerin kistllayıcı etkilerine rağmen kendi uygulamalarını faaliyette bulunduğu ülkelerdeki yerel şirketlere taşımaktadır.

Jarblad (2003, s. 6), çok uluslu şirketler ile ev sahibi ülkeler arasındaki bağımlılık ilişkilerini incelediği çalışmasında, potansiyel olarak çok uluslu şirketlerin üstünlüğ̈̈nü Şekil 2'de sunulan model ile özetlemiş̧ir. Çok uluslu şirketler ile ev sahibi ülkeler arasındaki bağımlılık ilişkileri modeli incelendiğinde, bağımlılık ilişkisinin asimetrik olduğu ve söz konusu bağımlılık ilişkisinin az gelişmiş veya gelişmekte olan ülkeler karşısında çok uluslu şirketlerden yana olduğu görülebilmektedir. Bu bağlamda, çok uluslu şirketlerin yerel baskıları göğüslemede çok fazla zorlanmayacağı öne sürülebilir. 
Şekil 2. Çok Uluslu Şirketler ile Ev Sahibi Ülkeler Arasındaki Bağımlılık İlişkileri Modeli

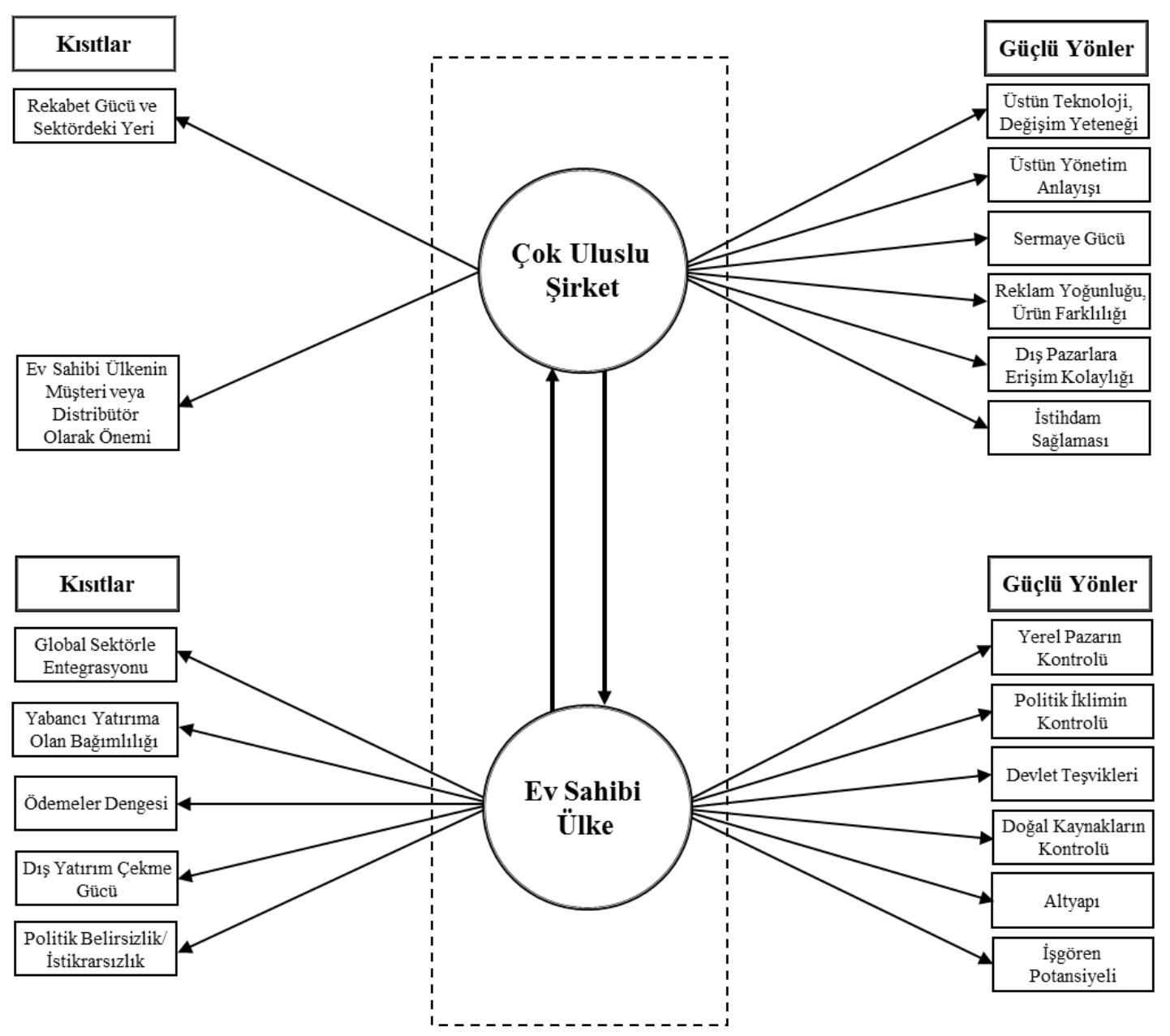

Kaynak: Jarblad, A. (2003). The international popularization of entrepreneurial ideas: The international popularization of entrepreneurial ideas, Luleå University of Technology C Extended Essay, 047, Luleå, İsveç.

Yerel baskılarla eşbiçimli hâle gelmesi ve meşruiyet kazanması öngörülen çok uluslu şirketlerin bu baskılara uymadığı veya uyuyormuş gibi yaptığına ilişkin örnekler aşağıda sunulmuştur.

Levi Strauss genel merkezi, 1991'de İspanya'da çalışanlarına asgari ücretten daha az ödeme yapması ve onları daha uzun süre çalıştırması baskıları yüzünden bu ülkedeki yatırım ve üretimlerini durdurmuştur,

- Tayvan ve Güney Kore'nin Japonya tarafından kendilerine otomobil ihraç edilmesini yasaklaması üzerine Honda, ABD’nin Ohio eyaletindeki fabrikası üzerinden söz konusu ülkelere ihracatını gerçekleştirmiştir,

- Polaroid, 1970'lerde Güney Afrika Cumhuriyeti’ndeki ırkçılık uygulamalarına katılmayı reddettiği için bu ülkedeki yatırımlarını sonlandırmış ve ayrılmıştır (Post vd., 1996), 
- Uzun süredir sosyal ve çevresel problemlere duyarsız kaldığı noktasında eleştirilen WalMart'ın, buna tepki olarak başlattığı halkla ilişkiler kampanyasında verdiği sözleri tutmadan yoluna eskisi gibi devam ettiği gözlemlenmiştir (Scherer, Palazzo ve Seidl, 2013, s. 270).

Önerme3: Çok uluslu şirketler, beğenmediği yerel uygulamaları değiştirmeye çalışılar, değiştiremiyorsa ev sahibi ülkedeki faaliyetlerine son verirler.

Yeni kurumsal kuram açısından çok uluslu şirketlerde meşruiyet kazanma ve eşbiçimlilik çabalarına yönelik analizi, Şekil 3’te görüldüğü üzere modellemek mümkündür.

Şekil 3. Yeni Kurumsal Kuram Açısından Çok Uluslu Şirketlerde Meşruiyet Kazanma ve Eşbiçimlilik Çabaları.

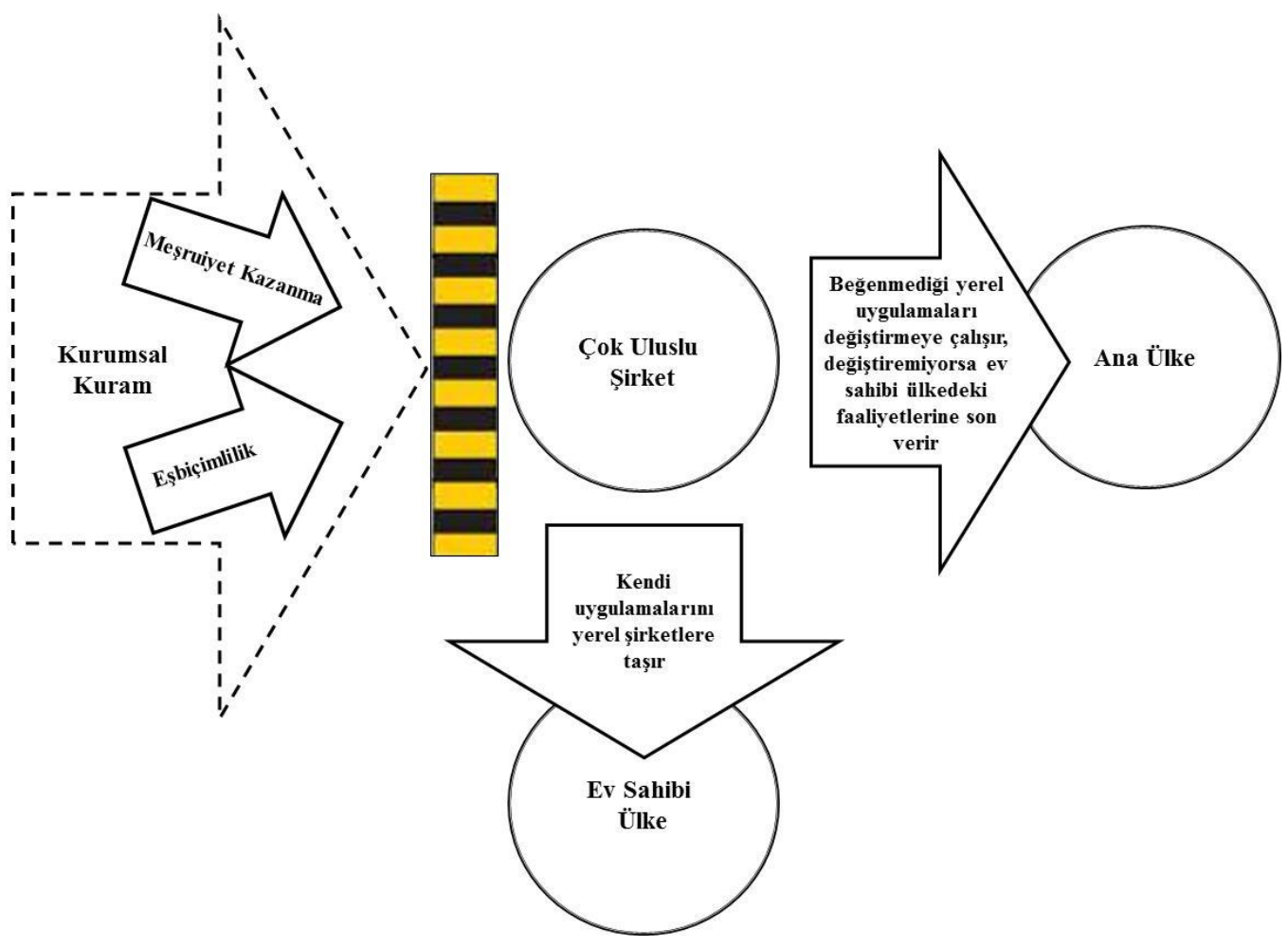

Makalenin bu bölümünde, çok uluslu şirketlerde yeni kurumsal kuramın öne sürdüğü meşruiyet kazanma ve eşbiçimlilik kavramları koşul bağımlılık kuramı bağlamında incelenmektedir.

\subsection{Yeni Kurumsal Kuramın Öne Sürdüğ̈̈ Kavramlardan Meşruiyet Kazanma ve}

\section{Eşbiçimliliğin Çok Uluslu Şirketlerde Koşul Bağımlılık Faktörleri Bağlamında İncelenmesi}

Daha önceki bölümlerde her koşulda geçerli tek bir örgüt yapısı bulunmadığı, yöneticilerin örgüt yapılarını içerisinde bulunduğu çevre, teknoloji, büyüklük ve strateji gibi koşul bağımlılık faktörlerine uyarlamaları gerektiği ifade edilmişti. Özellikle çevre ve teknolojinin örgütler için temel belirsizlik kaynağı olduğuna dikkat çekilmişti. Bu kapsamda çok uluslu şirketlerde meşruiyet kazanma ve eşbiçimlilik kavramları, koşul bağımlılık faktörlerinden çevre ve teknoloji özelinde incelenecektir.

Kurumsal çevreye uyumun meşruiyeti ve böylece de dışsal desteği sağladığı, koşul bağımlılık faktörlerine uyumun ise örgüt için üst derece içsel etkililiği sağladığı ifade edilmişti. Örgüt yapısının 
kurumsal çevreye mi yoksa koşul bağımlılık faktörlerine mi uyum sağlaması irdelendiğinde, eşanlı olarak içsel etkililiğin ve dışsal desteğin sağlandığına çok nadir rastlanıldığı (Donaldson, 2008a, s. 18) vurgulanmaktadır. Bu kapsamda, optimum çözümün sağlanması için ikisi arasında ödünleşme analizi yapılmalıdır (Donaldson, 2008b, s. 39). Çok uluslu şirketlerin dışsal çevreyle olan ilişkilerinde karşılaşabileceği zorlukları aşmada çoğunlukla küresel çapta marka oluşundan (Numerof vd., 2010, s. 33), sektör içerisindeki büyüklüğünden, patent ve telif hakları nedeniyle sahip olduğu rekabet ve piyasa gücünden (Hillman ve Wan, 2005, s. 327), yerel bağlantıları ile kurduğu ağlardan (Alimadadi ve Pahlberg, 2014, s. 339) ve operasyonel esneklikten (Song, 2015, s. 2) yararlandığı ve yapılarını değişen çevre koşullarına göre kendi insiyatifi ile uyumlandırdığı görülmektedir. Özellikle devlet kademeleri, iş dünyasının güçlü şirketleri ile sivil toplum örgütleri ile kurulacak bağlantılar büyük önem taşımaktadır. $\mathrm{Bu}$ bağlamda, değiş̧en çevresel şartlar, çok uluslu şirketleri sürekli olarak yenilik yaparak yeteneklerini rekabet edecek şekilde geliştirmeye (Sambharya ve Lee, 2014, s. 137) yöneltmektedir.

Önerme4: Çok uluslu şirketler, dlşsal çevreyle olan ilişkilerinde karşılaşabileceği problemleri, meşruiyet kazanma temelli eşbiçimlilik çabalart ile değil de, sahip olduğu özellikler ve kendi insiyatifi ile değisşen koşullara uyum sağlaması ile sağlarlar.

Çok uluslu şirketlerin maruz kaldı̆̆ı iç baskıların temelinde, ana merkezin kurumsallaşmış strateji ve uygulamaları ile uyumlu ve eşbiçimli olmaya (Kostova ve Zaheer, 1999, s. 72) çalışılıasının yattığı ifade edilmişti. Ana merkez, bunu başarmak için performans değerlendirmeleri, kaynakların dağııtılması, bütçe ve finansal teşviklerden (Rosenzweig ve Singh, 1991, s. 347) yararlanmaktadır. Uygulamaları ile tüm şirketlerini bütünleştiren ana merkez, elde ettiği sinerji ve dünyanın dört bir yanına dağılmış şirketleri arasındaki bilgi paylaşımı (Gupta ve Govindarajan, 1991, s. 773) ile, etkin ve etkili olunmasını sağlamaktadır.

İçsel meşruiyet ana merkezin strateji ve uygulamalarının kabulü ve onayladığı örgütsel yapının kullanılması (Hillman ve Wan, 2005, s. 328) ile kolaylıkla sağlanabilecektir. Bu bağlamda çok uluslu şirketlerin içsel etkililiğini, global çaptaki tüm şubeleri arasında kesintisiz strateji ve uygulamalarını içeren bilgi akışı ile sağlayabileceği (Tseng, 2015, s. 119) ifade edilebilir.

Önerme5: Çok uluslu şirketler, içsel çevreyle olan ilişkilerinde karşılaşabileceği problemleri, meşruiyet kazanma temelli eşbiçimlilik çabalart ile değil de, global çaptaki tüm şubeleri arasında kesintisiz bilgi akışı ile sağlarlar.

Çok uluslu şirketlerin tartışılması gereken en önemli özelliklerinden biri de sahip oldukları teknolojidir. Koşul bağımlılık faktörlerinden olan teknolojiden kasıt, bir örgütün üzerine dinamik yetenekler geliştirebileceği anahtar bir kaynak olduğudur. Teknoloji, örgütün kullandığ1 girdileri (hammadde, bilgi, enerji, sermaye vb.) ürün ve hizmet gibi çıktılara dönüştüren teknik ve işlemler olarak tanımlanabilir; kısaca patentler, eşsiz süreçler ve ticari sırlar içeren bilgidir (Tihanyi ve Roath, 2002). Teknolojinin baskın karakteristiği değişim, daha fazla değişimdir (Post vd., 1996, s. 499). Toffler'e göre ise teknoloji kendi kendini besler, teknoloji daha çok teknolojinin oluşumunu sağlar (Toffler, 1971, s. 26). $\mathrm{Bu}$ bağlamda sürekli olarak gelişen teknolojinin sebep olduğu yenilik ve buluşlar, örgütleri zorlayan en önemli baskılardandır. 
Çok uluslu şirketler çoğunlukla üst düzey üretim teknolojileri ile yerel şirketlere üstünlük sağlamaktadır (Cantwell ve Iammarino, 1998, s. 384). Çok uluslu şirketlerin dünya çapındaki şirketlerindeki örgütsel yapıların birbirine benzemesindeki nedenin sahip olunan teknolojinin yayılması ile ilgili olduğu (Rosenzweig ve Singh, 1991, s. 344) vurgulanmaktadır. Teknolojik gelişmeleri ürünlerine global çapta uygulayan çok uluslu şirketlerin, elde ettikleri başarı ile marka değerlerine ve sürdürülebilir rekabet avantajlarını ellerinde tuttukları gözden kaçırılmamalıdır.

Önerme6: Çok uluslu şirketler, marka değerleri ile yerel şirketler karşısındaki sürdürülebilir rekabet avantajlarını, sahip oldukları üstün teknolojileri ile sağlarlar.

Yeni kurumsal kuramın öne sürdüğü kavramlardan meşruiyet kazanma ve eşbiçimliliğin çok uluslu şirketlerde koşul bağımlılık faktörleri bağlamında incelenmesine yönelik analizi, Şekil 4 'te görüldüğü üzere modellemek mümkündür.

Şekil 4. Yeni Kurumsal Kuramın Öne Sürdüğü Kavramlardan Meşruiyet Kazanma ve Eşbiçimliliğin Çok Uluslu Şirketlerde Koşul Bağımlılık Faktörleri Bağlamında İncelenmesi.

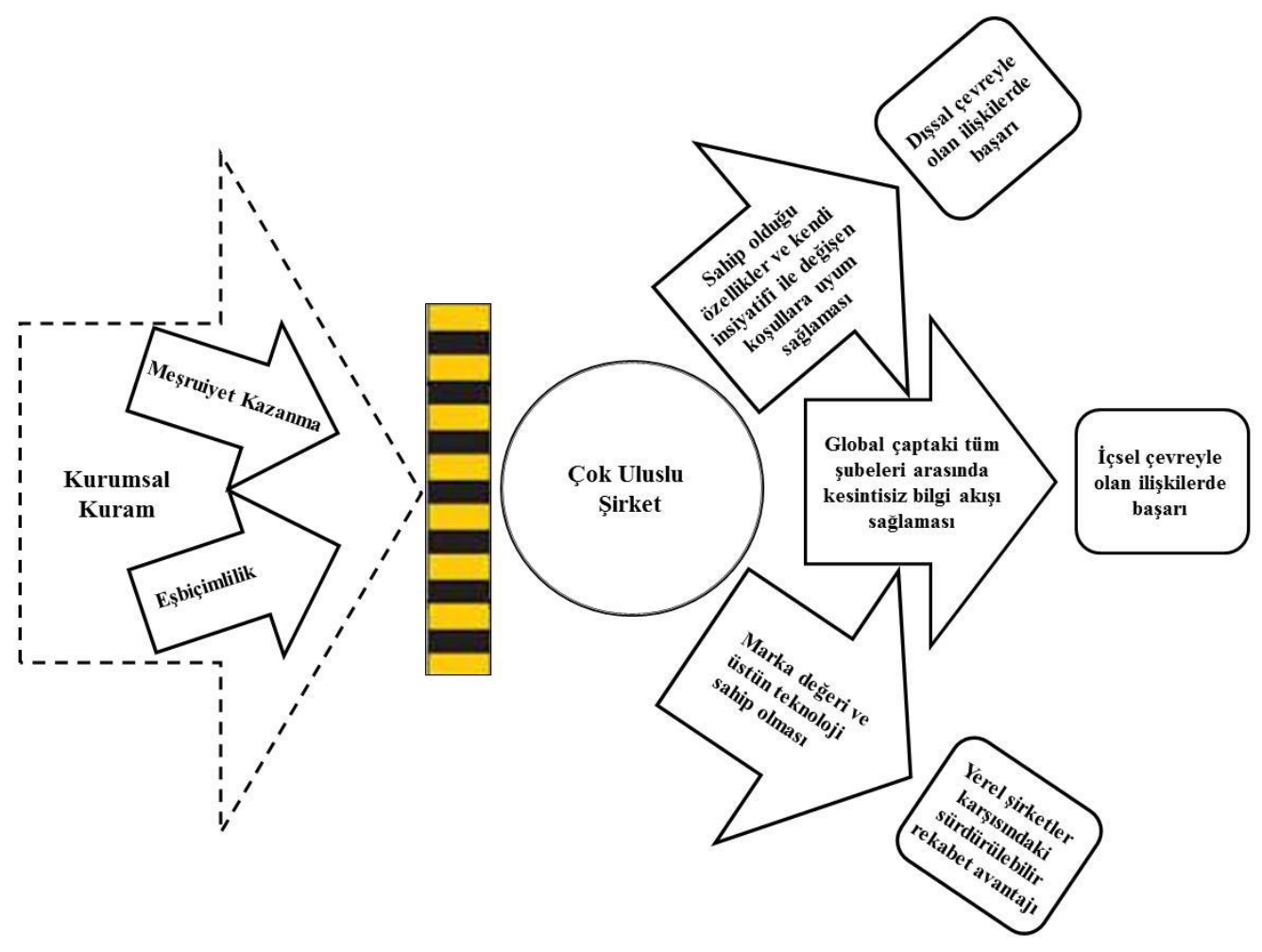

Tartışılan tüm konular ışığı altında meşruiyet kazanma ve eşbiçimlilik için gerekli başat unsurun, çok uluslu şirketin örgüt olarak bizzat kendisinden (Popadiuk vd., 2014, s. 470) ve kurumsal uygulamalarından kaynaklandığı vurgulanabilir. Söz konusu özelliklerin koşul bağımlılık faktörleri ve değişen şartlara göre ele alınmasının başarı şansını her daim artıracağı ifade edilebilir. Özellikle seçkin global perspektif sahibi yönetici ve çalışanları ile ekonomik çıkarlarını, ev sahibi ülkelerin ekonomik ve sosyal hassasiyetleri ile entegre etmelerinin (Post vd., 1996, s. 198) sahip oldukları üstünlüğü devam ettirmelerinin bir diğer unsur olduğu gözden kaçırılmamalıdır. 


\section{3. ÇIKARIMLAR VE SONUÇ}

$\mathrm{Bu}$ çalışmada, her ne kadar meşruiyet kazanma ve eşbiçimlilik kavramları kurumsal kurama ait kavramlar olsa da, söz konusu kavramların yerel şirketler için taşıdığı anlamın çok uluslu şirketlerde farklı etkilere sahip olabildiği ve koşul bağımlılık faktörlerine göre değişebildiği sorunsalından yola çıkılmıştır.

Yapılan inceleme neticesinde;

- Çok uluslu şirketlerin sahip oldukları teknolojik ve rekabet üstünlüğü ile güçlü finansal yapıları sebebiyle içerisinde yer aldıkları sektörde söz sahibi olmaları,

- Uluslararası boyutta yatay ve dikey bütünleşmelerle ortaya koydukları esnek ve dinamik örgüt yapıları,

- Global çapta meydana gelebilecek istikrarsızlıklardan etkilenme olasılıklarının görece düşük olmas1,

- Yerel kurumsal çevrenin çok uluslu şirketleri eşbiçimliliğe zorlayacak sınırlı kapasiteye sahip olmas1,

- Yerel çevrenin çok uluslu şirketlerin muhtaç olduğu tüm kaynakları kontrolü altında tutamamas1,

- Ev sahibi ülkenin çoğunlukla çok uluslu şirketler hakkındaki bilgisinin eksik olması,

- Çok uluslu şirketlerin izlemesi için oluşturulmuş kesin kurumsal formların mevcut olmaması,

- Çok uluslu şirketlerin yasal sınırlar içerisinde hareket ettiği sürece yerel kurumsal çevreyle olan ilişkilerini yönlendirmekte serbest olması ve

- Çok uluslu şirketlerin kendilerine özgü ve tahmin edilemeyen uygulamalarının mevcudiyeti, kısaca çok uluslu şirketlerin kendine özgü karmaşık doğasını yalnızca yeni kurumsal kuramın meşruiyet kazanma ve eşbiçimlilik kavramlarıyla açıklamanın mümkün olmadığı görülmektedir.

Çok uluslu şirket ne kadar büyük, ne kadar etkin ve ne kadar güçlü olursa olsun, ana ülkesinden ve karargâhından kaynaklanan ve uymak zorunda olduğu kurumsal kuralların yanında ev sahibi ülkenin yerel kurumsal kurallar ile karşı karşıyadır, bu nedenle de kurumsal ikilik içerisindedir (Kostova ve Roth, 2002, s. 216; Hillman ve Wan, 2005, s. 323). Bu duruma, içerisinde bulunulan bağlam ve şartlar eklendiğinde, çok uluslu şirketin nasıl davranması gerektiği süreci tamamen karmaşık bir hâl almaktadır. Ancak bu olumsuzluklara rağmen, ekonomik açıdan birçok ülkeden daha güçlü olan çok uluslu şirketlerin, ülkelerden farklı olarak kendileri dışında hiçbir kurum veya kuruluşa hesap vermedikleri, ana merkezleri tarafından sıkı bir şekilde kontrol edildikleri ve bu merkezlerde alınan karar ve politikalar çerçevesinde yerel insiyatifleri bastırarak hareket ettikleri görülmektedir.

Küreselleşen ekonominin kaynakları ülke sınırlarını aşan ve başka ülkelerin ekonomik, ticari, sosyal ve hukuki alanları içerisinde kalan, yeni ve değişik örgütsel konfigürasyonları ile çok uluslu şirketlerin; tek bir kurumsal çevrenin sınırları içerisinde hareket etmek zorunluluğunu ortadan kaldırdığ söylenebilir.

Bu çalışma ile çok uluslu şirketlerin meşruiyet kazanma ve eşbiçimlilik kavramlarını kurumsal kuram açısından irdeleyen çalışmalardan (Mueller, 1994; Zaheer, 1995; Post vd., 1996; Whitley, 1999; 
Kostova ve Zaheer, 1999; Hillman ve Hitt, 1999; Whitley, 2000; Jarblad, 2003; Hillman ve Wan, 2005; Kostova vd., 2008; Koene ve Ansari, 2011; Scherer vd., 2013) farklı olarak, söz konusu kavramlara koşul bağımlılık faktörlerinden çevre ve teknoloji açısından yaklaşılmıştır. Yapılan tartışma sonucunda elde edilen çıkarım; çok uluslu şirketler için meşruiyet kazanma temelli eşbiçimlilik çabalarının, başarılı olma ya da hayatta kalma şansını artırmak açısından gerek ve yalnız şart olmadığı yönündedir.

Daha sonra yapılacak çalışmaların koşul bağımlılık faktörlerinden büyüklük, strateji ve kültür açısından ele alınabileceği, elde edilecek bulguların çok uluslu şirketlerin kendine özgü karmaşık doğasının anlaşılması konusunda yeni ufuklara yelken açılmasına vesile olabileceği düşünülmektedir. Özellikle çok uluslu şirketlerin yatırım yaptığı veya faaliyette bulunduğu ülkelerde yaşayabileceği başarısızlığın önemli bir sebebin ev sahibi ülkenin sosyo-kültürel bağlamına duyarsız kalması olabileceği gözden kaçırılmamalıdır. Bu konuda meydana gelebilecek kültürel çatışmaların engellenmesi ve sinerji yaratılması maksadıyla, ana merkezdeki örgüt kültürü ile ev sahibi ülkenin yerel toplumsal kültürü arasında hibrid örgüt kültürü geliştirilmesi incelenebilecek ilgi çekici konular arasında yer alabilir.

\section{KAYNAKÇA}

Alimadadi, S. ve Pahlberg, C. (2014). A Network view of MNC embeddedness in a politically uncertain market: The case of Turkey. Business and Politics, 16(2), 339-372.

Alvarez, J.L. (1996). The international popularization of entrepreneurial ideas. S.R. Clegg ve G. Palmer (Ed.). The politics of management knowledge içinde (80-98). London: Sage.

Aydın, N. (1997). Uluslararası doğrudan yatırımlar ve ortak girişimler (Joint Ventures), Eskişehir: T.C.Anadolu Üniversitesi Yayınları, 1002.

Banalieva E.R. ve Sarathy, R. (2011). A contingency theory of internationalization performance for emerging market multinational enterprises. Management International Review, 51, 593-634.

Basler, B. (6 Şubat 1989). International report; Marriott defies a Hong Kong custom, the New $\begin{array}{lllll}\text { York Times. } & \text { Erişim } & \text { Mart }\end{array}$ http://www.nytimes.com/1989/02/06/business/international- report-marriott-defies-ahong-kong-custom.html

Bertalanffy, L.V. (1950). An outline of general system theory. The British Journal for the Philosophy of Science, 1(2), 134-165.

Bolat, T. ve Seymen, O.A. (2006). Yönetim ve örgüt düşüncesinde kurumsalcılık, yeni kurumsalcılık ve kurumsal eşbiçimlilik. Fırat Üniversitesi Sosyal Bilimler Dergisi, 16(1), 223-254.

Blau, P.M. (1970). A formal theory of differentiation in organization. American Sociological Review, 35, 201-218.

Burns, T. ve Stalker, G. (1961). The management of innovation. London: Tavistock.

Cantwell, J. ve Iammarino, S. (1998). MNCs, technological innovation and regional systems in the EU: Some evidence in the Italian case. International Journal of the Economics of Business, 5(3), 383-408. 
Chandler, A.D. (1962). Strategy and structure, chapters in the history of the American industrial enterprise. Cambridge, Massachusetts: MIT Press.

Cohen, G. (2006). Barriers to marketing within professional service firms. PhD Thesis, Brunel Business School, Brunel University, London.

Çakar, M. ve Danışman, A. (2012). Kurumsal kuram. H.C. Sözen ve H.N. Basım (Ed.). Örgüt kuramları içinde (241-269). Ankara: Beta Basım AŞ.

Deephouse, D.L. (1996). Does isomorphism legitimate? Academy of Management Journal, 39(4), 1024-1039.

Dimaggio, P.J. ve Powell, W.W. (1983). The iron cage revisited: Institutional isomorphism and collective rationality in organizational fields. American Sociological Review, 48(2), $147-$ 160 .

Dimaggio, P.J. ve Powell, W.W. (1991). The iron cage revisited: Institutional isomorphism and collective rationality in organizational fields. W.W. Powell ve P.J. Dimaggio (Ed.). The new institutionalism in organizational analysis içinde (63-82). Chicago: The University of Chicago Press.

Donaldson, L. (1996). The normal science of structural contingency theory. S.R. Clegg, C.Hardy ve W.R. Nord (Ed.). Handbook of organization studies içinde (57-76), London: Sage Publications.

Donaldson, L. (2001). The contingency theory of organizations. London: Sage Publications.

Donaldson, L. (2008a). The conflict between contingency and institutional theories of organizational design. R.M. Burton, B.H. Eriksen, D.D. Håkonsson, T. Knudsen ve C.C. Snow (Ed.). Designing organizations: $21^{\text {st }}$ century approaches içinde (3-20). New York: Springer Science + Business Media.

Donaldson, L. (2008b). Resolving the conflict between contingency and institutional theories of organizational design. R.M. Burton, B.H. Eriksen, D.D. Håkonsson, T. Knudsen ve C.C. Snow (Ed.). Designing organizations: $21^{\text {st }}$ century approaches içinde (21-40). New York: Springer Science + Business Media.

Dunning, J.H. (2000). The Eclectic Paradigm as an envelope for economic and business theories of MNE activity. International Business Review, 9(2), 163-190.

Duncan, R.B. (1972). Characteristics of organizational environment and perceived environmental uncertainty. Administrative Science Quarterly, 17(3), 313-327.

Eisenhardt, K.M. ve Schoonhoven, C.B. 1996. Resource-based view of strategic alliance formation: Strategic and social effects in entrepreneurial firms. Organization Science, 7 , 136-150.

Emery, F. ve Trist, E. (1965). The causal texture of organizational environments. Human Relations, 18(1), 21-32.

Giddens, A. (1996). The consequences of modernity. Oxford: Blackwell Publishers Ltd.

Gökşen, N.S. (2010). Makrokurumsal bakiş açisi: Bir değerlendirme. A.S. Sargut ve Ş. Özen (Ed.). Örgüt kuramları içinde 331-378. Ankara: İmge Kitabevi. 
Gupta, A.K. ve Govindarajan, V. (1991). Knowledge flows and the structure of control within multinational corporations. Academy of Management Review, 16, 768-792.

Harzing, A.W. ve Sorge, A. (2003). The relative impact of country-of-origin and universal contingencies on internationalization strategies and corporate control in multinational enterprises: World-wide and European perspectives. Organization Studies, 24(2), 187214.

Hasselbladh, H. ve Kallinikos, J. (2000). The project of rationalization: a critique and reappraisal of neo-institutionalism in organization studies. Organization Studies, 21(4), 697-720.

Hillman, A. ve Hitt, M.A. (1999). Corporate political strategy formulation: A model of approach, participation level and strategy decisions. Academy of Management Review, 24, 825-842.

Hillman, A.J ve Wan, W.P. (2005). The determinants of MNE subsidiaries' political strategies: Evidence of institutional duality. Journal of International Business Studies, 36(3), 322340.

İlhan, T. (2005). Uluslararası ortak girişimlerde şirket içi tutarlılık ve yerel eşbiçimlilik baskılarını yönetmede farklılaşan stratejik insan kaynakları uygulamalarının rolü. Yönetim Araştırmaları Dergisi, 5(2), 81-119.

Jarblad, A. (2003). The international popularization of entrepreneurial ideas: The international popularization of entrepreneurial ideas. Luleå University of Technology C Extended Essay-047, Luleå, İsveç.

Koene, B. ve Ansari, S. (2011). Institutional change and the multinational change agent. Journal of Organizational Change Management, 24(4), 511-531.

Kostova, T. ve Zaheer, S. (1999). Organizational legitimacy under conditions of complexity: The case of the multinational enterprise. Academy of Management Review, 24(1), 64-81.

Kostova, T. ve Roth, K. (2002). Adoption of organizational practice by subsidiaries of multinational corporations: institutional and relational effects. Academy of Management Journal, 45(1), 215-233.

Kostova, T., Roth, K. ve Dacin, M.T. (2008). Institutional theory in the study of multinational corporations: A critique and new directions. Academy of Management Review, 33(4), 994-1006.

Lawrence, P.R. ve Lorsch, J.W. (1967). Differentiation and integration in complex organizations. Administrative Science Quarterly, 12(1), 1-47.

Mathews, J.A. (2006). Dragon Multinationals: New Players in 21st Century Globalization. Asia Pacific J Manage, 23, 5-27.

McIntyre, J. ve Ivanaj, V. (2009). Multinational enterprises and sustainable development: A review of strategy process research. J. McIntyre, S. Ivanaj ve V. Ivanaj (Ed.). Multinational enterprises and the challenge of sustainable development içinde (3-27), Massachusetts: Edward Elgar Publishing, Inc.

Meyer, J.W. ve Rowan, B. (1977). Institutionalized organizations: Formal structure as myth and ceremony. The American Journal of Sociology, 83(2), 340-363. 
Meyer, J.W. ve Scott, W.R. (1983). Organizational environments-rituals and rationality. Beverly Hills, CA: Sage.

Morgan, G. (1994). Images of organization. Thousand Oaks, CA: Sage.

Mueller, F. (1994). Societal effect, organizational effect, and globalization. Organization Studies, 15(3), 407-28.

Neuman, M. (2012).The image of the institution: a cognitive theory of institutional change. Journal of the American Planning Association, 78(2), 139-156.

Numerof, R.E., Ott, B. ve Abrams, M. (2010). Grow it globally. Marketing Management, 19(1), 30-35.

Oksay, S. (1998). Çokuluslu şirketler teorileri çerçevesinde, yabancı sermaye yatrımlarının incelenerek, değerlendirilmesi. DTM Dergisi, 3(8), 18-39.

Özen, Ş. (2010). Yeni kurumsal kuram: örgütleri çözümlemede yeni ufuklar ve yeni sorunlar. A.S. Sargut ve Ş. Özen (Ed.). Örgüt kuramları içinde (237-330). Ankara: İmge Kitabevi.

Perrow, C. (1967). Framework for comparative analysis of organizations. American Sociological Review, 32(2), 194-208.

Popadiuk, S., Rivera, E.R. ve Bataglia, W. (2014). Heterogeneity of isomorphic pressures: Intertwining the resource-based view and the neoinstitutional approach. Brazilian Administrative Review (BAR), 11(4), 455-475.

Post, J.E., Lawrence, A.T., Weber, J. ve Weber J. (1996). Business and society: corporate strategy, public policy, ethics, $8^{\text {th }}$ Ed. New York: McGraw-Hill.

Pugh, D.S., Hickson, D., Hinings, C. ve Turner, C. (1969). The context of organization structures. Administrative Science Quarterly, 14(1), 91-115.

Robertson, R. (1998). Globalization: social theory and global culture. London: Sage Publications.

Rosenzweig, P.M ve Singh, J.V. (1991). Organizational environments and the multinational enterprise. Academy of Management Review, 16(2), 340-361.

Roth, K. ve Kostova, T. (2003). The use of multinational corporation as a research context. Journal of Management, 29(6), 883-902.

Sally, R. (1995). States and firms, multinational enterprises in institutional competition. London: Routledge.

Sargut, A.S. (2009). Türkiye'de işletme yönetimi eğitiminin kurumsal çerçevesi: Çeşitlilikten eşbiçimliliğe. Eskişehir Osmangazi Üniversitesi İ̈BF Dergisi, 4(1), 51-63.

Sargut, A.S. (2010). Yapısal koşul bağımlılık kuramının örgütsel çevre kavramları bağlamındaki yeri. A.S. Sargut ve Ş. Özen (Ed.). Örgüt kuramları içinde (35-75). Ankara: İmge Kitabevi.

Sargut, A.S. (2012). Kamu örgütleri kuramını arıyor: Kurumsal bir yaklaşım. B. Aykaç, Ş. Durgun ve H. Yayman (Ed.). Türkiye'de kamu yönetimi içinde (239-254). Ankara: Nobel Yayın Dağıtım. 
Scherer, A.G., Palazzo, G. ve Seidl, D. (2013). Managing legitimacy in complex and heterogeneous environments: Sustainable development in a globalized world. Journal of Management Studies, 50(2), 259-284.

Scott, W.R. ve Meyer, J.W. (1991). The organization of societal sectors: propositions and early evidence. W.W. Powell ve P.J. Dimaggio (Ed.). The new institutionalism in organizational analysis içinde (108-140). Chicago: The University of Chicago Press.

Scott, W. (1995). Institutions and organizations. Thousand Oaks, CA: Sage.

Scott, W.R. (2003). Institutional carriers: Reviewing modes of transporting ideas over time and space and considering their consequences. Industrial and Corporate Change, 12(4), 879894.

Selznick, P. (1996). Institutionalism “old” and “new”. Administrative Science Quarterly, 41, 270277.

Sklair, L. (2002). Capitalism and development. London: Routledge.

Sambharya, R.B. ve Lee, J. (2014). Renewing dynamic capabilities globally: An empirical study of the world's largest MNCs. Management International Review, 54, 137-169.

Song, S. (2015). Inter-country exchange rates and intra-firm trade flow within global network of multinational corporations. Management International Review, 54, 1-22.

Suddaby, R. ve Greenwood, R. (2005). Rhetorical Strategies of Legitimacy. Administrative Science Quarterly, 50, 35-67.

Tihanyi, L. ve Roath, A. S. (2002). Technology transfer and institutional development in Central and Eastern Europe. Journal of World Business, 37(3), 188-198.

Tseng, C. (2015). Determinants of MNC's knowledge inflows to subsidiaries: A perspective on internalization advantages. Management International Review, 55, 119-150.

Thompson, J.D. (1967). Organizations in action: Social science bases of administrative theory. New York: McGraw-Hill.

Toffler, A. (1971). Future shock. New York: Bantam Books.

Türker, M. ve Örerler, E.O. (2004). Türk şirketerinin küresel şirket hâline getirilmesi yollarl. İstanbul: İTO Yayınları No. 2004-60.

Tüzün, İ.K. (2012). Yönetimde erken dönem: klasik ve neoklasik yaklaşımlar. H.C. Sözen ve H.N. Basım (Ed.). Örgüt kuramları içinde (11-33). Ankara: Beta Basım AŞ.

UN Statistics Division, National Accounts Main Aggregates Database, Erişim 22 Şubat 2016, http://unstats.un.org/unsd/snaama/dnllist.asp

Whitley, R. (1999). Divergent capitalisms, the social structuring and change of business systems. New York: Oxford University Press.

Whitley, R. (2000). The institutional structuring of innovation strategies: Business systems, firm types and patterns of technical change in different market economies. Organization Studies, 2 (5), 855-886.

Woodward, J. (1965). Industrial organization: theory and practice. New York: Oxford University Press. 
Çok Uluslu Şirketlerde Kurumsal Kuramın Öngördüğ̈̈ Meşruiyet Kazanma Ve Eşbiçimlilik Çabalarına Koşul Bağımlılık Kuramı Açısından Bir Bakıs - An Overview From The Contingency Theory Perspective On Legitimization And Isomorphism Efforts Envisaged By Institutional Theory In Multinational Corporations Cem ŞEN

Zaheer, S. (1995). Overcoming the liability of foreignness. Academy of Management Journal, 38, 341-363. 